\title{
Effect of magnetic field on biomass properties and their role in biodegradation under condition of low dissolved oxygen
}

\author{
Nur Syamimi Zaidi ${ }^{1,2}$ (D) Johan Sohaili ${ }^{1} \cdot$ Khalida Muda $^{1} \cdot$ Mika Sillanpää $^{3,4} \cdot$ Norelyza Hussein $^{1}$
}

Received: 15 November 2019 / Accepted: 27 May 2021 / Published online: 20 June 2021

(c) The Author(s) 2021

\begin{abstract}
Low condition of dissolved oxygen (DO) is commonly associated with sludge bulking problem that was able to disrupt the efficiency of wastewater treatment performances. Relatively, very little attention was paid to the possibility of applying magnetic field in controlling the bulking problem. Hence, this study aims to investigate the performance of magnetic field on biomass properties and its effect on biodegradation under low condition of DO. Two continuous laboratory-scale sequencing batch reactors-Reactor $A\left(S_{B R}\right)$ and Reactor $B\left(S_{B} R_{B}\right)$-were setup. $S_{B R}$ was equipped with the magnetic device to exhibit magnetic field of $88 \mathrm{mT}$, while $\mathrm{SBR}_{\mathrm{B}}$ acted as a control system. The results showed that the biomass concentration in $\mathrm{SBR}_{\mathrm{A}}$ was higher compared to $\mathrm{SBR}_{\mathrm{B}}$. High biomass concentration in $\mathrm{SBR}_{\mathrm{A}}$ resulted to better settleability with mean SVI of less than $30 \mathrm{~mL} / \mathrm{g}$. $\mathrm{SBR}_{\mathrm{A}}$ also showed consistently high removal performances of organic and inorganic contents compared to $\mathrm{SBR}_{\mathrm{B}}$. These observations confirmed that the magnetic field was able to enhance the biomass properties, which further enhance the biodegradation ability of the aerobic bacteria under low DO condition. This also indicates that under the sludge bulking circumstances, the use of magnetic field stands a great chance in maintaining high biodegradation of the treatment system.
\end{abstract}

Keywords Low dissolved oxygen $\cdot$ Sludge bulking $\cdot$ Magnetic field $\cdot$ Biomass $\cdot$ Biodegradation

\section{Introduction}

In conventional activated sludge (CAS) systems, solid-liquid separation is performed in the secondary clarifier after the biological reaction tank, though a phase separation problem has not been completely solved to-date. As a major separation problem, bulking causes the washout of suspended solids from the clarifier, decreases the biomass concentration in the reaction tank, with poor waste activated sludge

Nur Syamimi Zaidi

nursyamimi@utm.my

1 School of Civil Engineering, Faculty of Engineering, Universiti Teknologi Malaysia, UTM Johor Bahru, 81310 Johor, Malaysia

2 Centre for Environmental Sustainability and Water Security (IPASA), Universiti Teknologi Malaysia, UTM Johor Bahru, 81310 Johor, Malaysia

3 Institute of Research and Development, Duy Tan University, Da Nang 550000, Vietnam

4 Faculty of Environment and Chemical Engineering, Duy Tan University, Da Nang 550000, Vietnam thickening and dewatering characteristics (Wanner and Jobbágy 2014; Nittami et al. 2019). Bulking is usually caused by excessive proliferation of filamentous microorganisms, which appears to interfere with the sedimentation and compaction efficiency of the flocs.

There are many factors that contribute toward proliferation of filamentous microorganisms. Among all, dissolved oxygen (DO) is one of the prominent factors that can induce the filamentous growth, thus causing the bulking occurrence (Van den Akker et al. 2010). In the CAS system, low DO concentration such as $0.4 \mathrm{mg} / \mathrm{L}$ can produce long and regular filaments. Cultures of microthrix parvicella can grow under a wide range of oxygen partial pressures, and good growth is obtained under microaerophilic conditions (Rossetti et al. 2005). Low DO conditions seem to be beneficial for the growth of this microorganisms, thus providing a metabolic advantage for the proliferation of microthrix parvicella in the CAS treatment system (Rossetti et al. 2005). Nittami et al. (2019) reported that aside than $\mathrm{pH}$ and ammonium ion $\left(\mathrm{NH}_{4}{ }^{+}\right)$, DO concentration was significantly influenced the Kouleothrix (Type 1851 filamentous species). The decreased DO led toward high relative abundance of Kouleothrix, 
which consequently resulted toward high sludge volume index (SVI) of the biomass.

In order to control the occurrence of bulking, various types of methods were employed (Jenkins et al. 2004; Tandoi et al. 2006). Among them were non-specific methods such as chlorination, addition of hydrogen peroxide and many others. These methods aimed at improving the settling properties of the sludge without eliminating the cause of problem. For instance, aluminum and iron chloride have been used to a biological nutrient removal pilot plant at various concentrations to evaluate the effect of metallic salts on proliferation of microthrix parvicella. The results indicated that dosing a relatively low concentration of $41 \mathrm{mmol} / \mathrm{kg}$ could only keep the diluted sludge volume index (DSVI) constant, and microthrix parvicella filaments were still free in the water phase, while higher concentrations (94 and $137 \mathrm{mmol}$ ) significantly improved the settleability (Durban et al. 2016). The implementation of these methods, however, has serious drawbacks such as high cost, increase sludge volume and interference to a nitrification process (Jenkins et al. 2004). Some of the chemicals used such as bactericides are toxic for floc-forming bacteria (Du et al. 2018; Fan et al. 2018; Nittami et al. 2019).

Other attempts to avoid bulking problems include applying specific methods such as by raising the sludge load (Fan et al. 2018), reducing the substrate levels (Noutsopoulos et al. 2010), increasing the DO concentration (Jenkins et al. 2004; Deepnarain et al. 2015) and many others. These measures, however, were not quite effective. Some of the measures were time-consuming, costly and only suppress selective species of filamentous microorganisms. Relatively to-date, very little attention was paid to the possibility of applying magnetic field in controlling sludge bulking and further suppressing the filamentous microorganisms in the CAS treatment system. Previous research showed that application of magnetic field has significant improvement on the CAS treatment system through enhancement of the biomass (Křiklavová et al. 2014; Zaidi et al. 2016) and sludge settleability (Wang et al. 2012; Zaidi et al. 2014). A magnetic field was also reported as having significant influence on bacterial activity (Filipič et al. 2012; Yin et al. 2015) and few species of filamentous bulking and foaming microorganisms (Zaidi et al. 2018). Nonetheless, the relationship of magnetic field was toward biomass under limited DO condition while maintaining greater degradation performance.

Therefore, the aim of this work is to investigate the feasibility of having low dissolved oxygen on biomass under the application effect of magnetic field. The influences of magnetic field on physical characteristics, such as aggregation, sludge volume index, relative hydrophobicity and surface charge as well as removal performance of the biomass were monitored using controlled laboratory-scale sequencing batch reactor (SBR) system.

\section{Materials and methods}

\section{Wastewater and activated sludge}

Raw municipal wastewater sampled from the Indah Water Konsortium treatment plant was used in this study. The sampling was taken once a week and preserved in the cool room at temperature of below $4{ }^{\circ} \mathrm{C}$. The biomass used in this study was also collected from the same sewage treatment plant. The activated sludge was sampled in the aeration tank. The sludge inoculums were sieved with a mesh of $1.0 \mathrm{~mm}$ to remove large debris and inert impurities.

\section{Experimental setup and operational conditions}

Two laboratory-scale sequencing batch reactors-Reactor $\mathrm{A}\left(\mathrm{SBR}_{\mathrm{A}}\right)$ and Reactor $\mathrm{B}\left(\mathrm{SBR}_{\mathrm{B}}\right)$ - were designed with a working volume of $6 \mathrm{~L}$. $\mathrm{SBR}_{\mathrm{A}}$ was equipped with the magnetic device, while $\mathrm{SBR}_{\mathrm{B}}$ acted as a control system. The magnetic device that attached to the $\mathrm{SBR}_{\mathrm{A}}$ comprised series of permanent magnets arranged in an alternate order. Each permanent magnet was a square prism with two faces of $100 \mathrm{~mm} \times 50 \mathrm{~mm}$ and a thickness of $5 \mathrm{~mm}$. The applied magnetic field was at intensity of about $88.0 \mathrm{mT}$.

During the start-up period, $3 \mathrm{~L}$ of sludge and $3 \mathrm{~L}$ of wastewater were added into the reactor system making the final volume of $6 \mathrm{~L}$ with a total sludge biomass concentration of $5.6 \mathrm{~g} / \mathrm{L}$. $\mathrm{SBR}_{\mathrm{A}}$ and $\mathrm{SBR}_{\mathrm{B}}$ were operated in parallel with hydraulic retention time (HRT) of 8-h in 3 successive cycles. Each cycle comprised of $10 \mathrm{~min}$ filling, $380 \mathrm{~min}$ reaction, $80 \mathrm{~min}$ settling and $10 \mathrm{~min}$ decanting. The volumetric exchange rate (VER) was fixed at $50 \%$. The temperature of the systems was constant at $25{ }^{\circ} \mathrm{C}$, while the $\mathrm{pH}$ throughout the experiments was between 6.0 and 8.0. In this study, the dissolved oxygen (DO) concentration was set from 0.5 to $2.0 \mathrm{mg} / \mathrm{L}$ in order to induce the sludge bulking condition. The level of DO concentration was monitored using DO meter that was installed to the reactors. The aeration intensity was the parameter that has been continuously monitored to ensure the level of DO concentration was within the specified range.

\section{Analytical methods}

For physical characterization, the sample was analyzed for biomass concentration (MLSS and MLVSS), sludge volume index (SVI), aggregation, relative hydrophobicity and surface charge. In this study, MLSS, MLVSS and SVI were conducted based on APHA (2005)—Method No. 2540D, $2540 \mathrm{E}$ and 2710D, respectively. Aggregation was evaluated in terms of turbidity measurement (Rahman et al. 2008). 
Relative hydrophobicity of the biomass was measured as adherence to hydrocarbons (Chang and Lee 1998), while surface charge was determined by colloidal titration (Morgan et al. 1990).

For removal performances of the system, several parameters were determined including chemical oxygen demand (COD), ammonia-nitrogen, nitrite, nitrate and phosphorus. These parameters were conducted based on Standard Method APHA (2005).

\section{Results and discussions}

\section{Physical profile of the reactor systems}

The profile of dissolved oxygen (DO) concentration for both reactors is shown in Fig. 1. The DO concentration for both reactors was very low which was between the 0.5 and $2.0 \mathrm{mg} / \mathrm{L}$. For $\mathrm{SBR}_{\mathrm{A}}$, the average DO concentration was $1.09 \mathrm{mg} / \mathrm{L}$, while for $\mathrm{SBR}_{\mathrm{B}}$ the average $\mathrm{DO}$ concentration was $0.96 \mathrm{mg} / \mathrm{L}$. Meanwhile, the average values of biomass properties are shown in Table 1 . Based on the respective table, the mean SRT was $12.3 \pm 0.2$ day for $\mathrm{SBR}_{\mathrm{A}}$ and $11.5 \pm 0.8$ day for $\mathrm{SBR}_{\mathrm{B}}$. The $\mathrm{SRT}$ value changes throughout the experimental period. According to Wijffels and Tramper (1995), the favorable sludge age of more than 4 days can result in high removal efficiency especially for COD and nitrification process. Based on the SRT obtained under low DO concentration, both reactors are able of simultaneous nitrification-denitrification process and COD removal.

During the experimental period, ratio between mixed liquor volatile suspended solids (MLVSS) and mixed liquor suspended solids (MLSS) were nearly constant with an average value of $0.81 \pm 0.06$ for $\mathrm{SBR}_{\mathrm{A}}$ and $0.77 \pm 0.06$ for $\mathrm{SBR}_{\mathrm{B}}$. Meanwhile, the accumulation of suspended solids
Table 1 Average values of biomass properties for $\mathrm{SBR}_{\mathrm{A}}$ and $\mathrm{SBR}_{\mathrm{B}}$

\begin{tabular}{lcc}
\hline Parameter & $\mathrm{SBR}_{\mathrm{A}}$ & $\mathrm{SBR}_{\mathrm{B}}$ \\
\hline MLSS (g/L) & $5.5 \pm 0.7$ & $4.5 \pm 0.7$ \\
MLVSS (g/L) & $4.5 \pm 0.8$ & $3.5 \pm 0.6$ \\
MLVSS/MLSS & $0.81 \pm 0.06$ & $0.77 \pm 0.06$ \\
TSS (mg/L) & $127.1 \pm 18.7$ & $143.4 \pm 20.5$ \\
VSS (mg/L) & $118.6 \pm 15.6$ & $137.6 \pm 20.3$ \\
SRT (d) & $12.3 \pm 0.2$ & $11.5 \pm 0.8$ \\
\hline
\end{tabular}

in the effluent was observed lower in $\mathrm{SBR}_{\mathrm{A}}$ compared to $\mathrm{SBR}_{\mathrm{B}}$. This observation confirmed the theories predicted the effect of magnetic field in accelerating the coagulation and sedimentation of the particles (Oka et al. 2009; Zaidi et al. 2014). According to Jin et al. (2003), the practical activated sludge originally contained iron. Sedimentation enhancement with facilitation of magnetic field was closely related with iron in the activated sludge. Iron in the activated sludge could be derived from some materials used in the domestic sewage wastewater (Park et al. 2006). Iron compounds in activated sludge were magnetized with the applied magnetic field, thus increased the attraction between cells and further caused the floc size to be enlarged. This process consequently improved the sedimentation and resulted in low suspended solids as has been indicated in $\mathrm{SBR}_{\mathrm{A}}$. Such results were then led in high MLSS in the reactor as less sludge washout occurred in $\mathrm{SBR}_{\mathrm{A}}$.

Figure 2 shows the changes of biomass concentration (MLSS) for $\mathrm{SBR}_{\mathrm{A}}$ and $\mathrm{SBR}_{\mathrm{B}}$ throughout the experimental period. For $S_{B R}$ specifically, on day 21, the MLSS of the sludge decreased steeply. This could be attributed by instability of the system, which normally occurred during the early state of the experiment. After day 21, the MLSS of in $\mathrm{SBR}_{\mathrm{A}}$ was slightly increased again and reached about $7.0 \mathrm{~g} / \mathrm{L}$
Fig. 1 Profile of dissolved oxygen (DO) concentration for $\mathrm{SBR}_{\mathrm{A}}$ and $\mathrm{SBR}_{\mathrm{B}}$
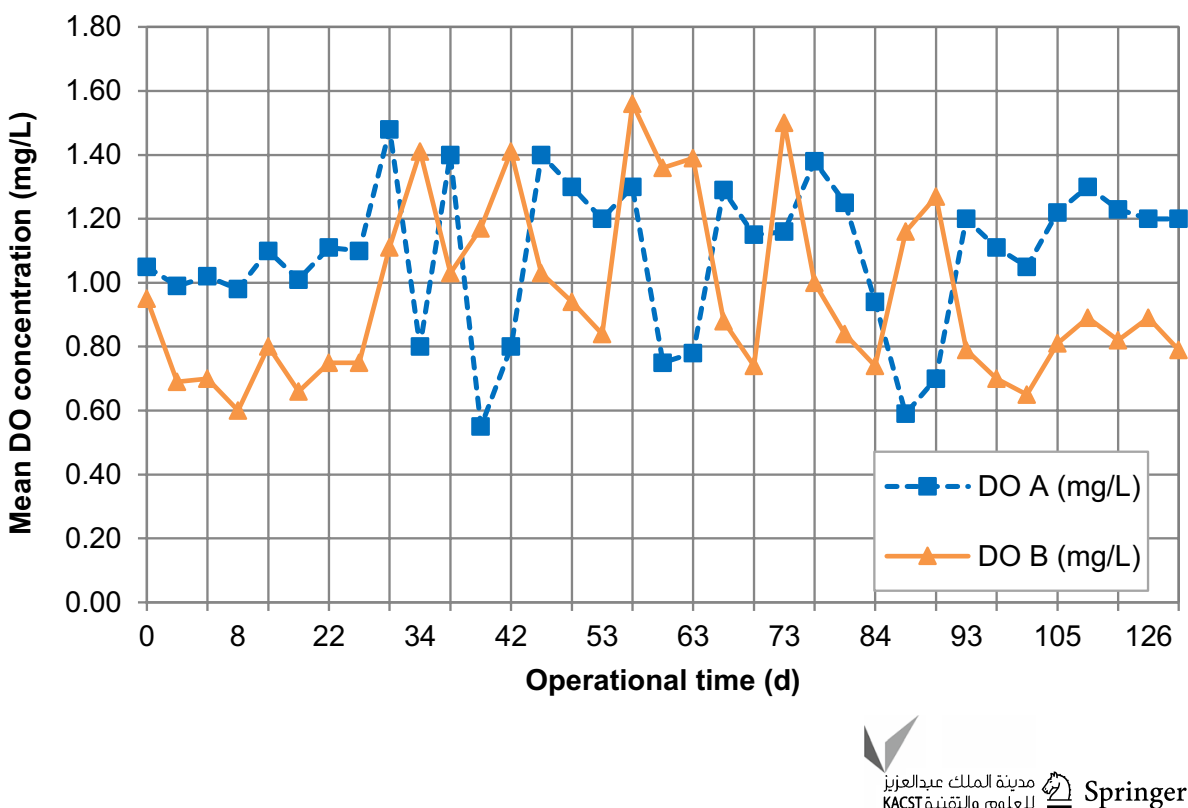
Fig. 2 Profile of biomass concentrations (MLSS) for $\mathrm{SBR}_{\mathrm{A}}$ and $\mathrm{SBR}_{\mathrm{B}}$

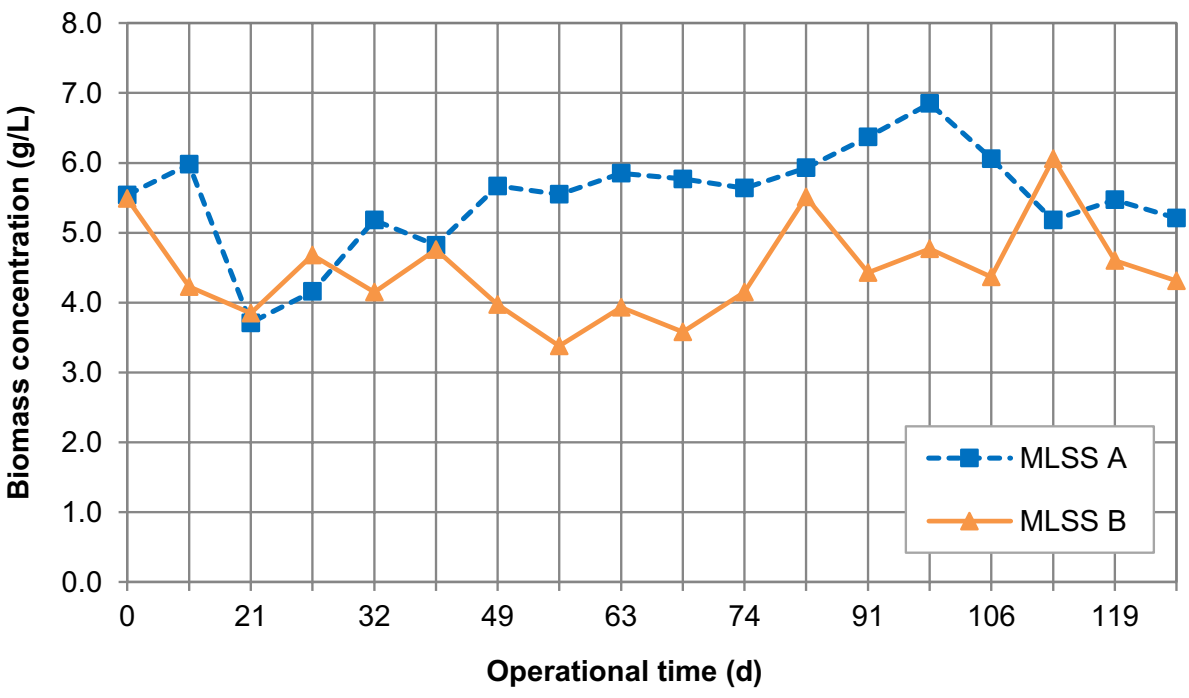

on day 99 and decreased to $5.5 \mathrm{~g} / \mathrm{L}$ in average toward end of the experiment. In contrast of such observations, MLSS in $\mathrm{SBR}_{\mathrm{B}}$ showed relatively continuous fluctuation throughout the experimental period, suggesting that the steady-state phase was hard to be achieved.

Despite the condition of low DO concentration that has been illustrated in the profile of DO concentration (Fig. 1), $\mathrm{SBR}_{\mathrm{A}}$ was evidenced in retaining high biomass concentration compared to $\mathrm{SBR}_{\mathrm{B}}$. Such observations in $\mathrm{SBR}_{\mathrm{A}}$ can be explained due to the changes applied in the conventional activated sludge system by attaching the magnetic field device. This is because the magnetic field might influence the microbial community compositions and their metabolisms, which could further affect the biomass characteristics. The magnetic field was evidenced in able to trigger the microorganisms to produce extra-polymeric substances
(EPS) (Wang et al. 2012; Zaidi et al. 2019a). The presence of EPS could then increase the adhesion ability of microorganisms (Sheng et al. 2010). This occurrence could then inhibit the sludge loss, which can explain on high biomass concentration in $\mathrm{SBR}_{\mathrm{A}}$ over $\mathrm{SBR}_{\mathrm{B}}$.

\section{Physical properties of biomass upon the effect of magnetic field under low DO condition}

Figure 3 shows a relationship between aggregation and SVI for both reactors under the defined experimental condition. It can be seen that increase in aggregation led to the decrease in SVI.

Figure 3 shows that the biomass in $\mathrm{SBR}_{\mathrm{A}}$ obtained mostly high aggregation compared to $\mathrm{SBR}_{\mathrm{B}}$. This resulted in lower SVI with an average of less than $30 \mathrm{~mL} / \mathrm{g}$
Fig. 3 Aggregation and SVI profiles of biomass for $\mathrm{SBR}_{\mathrm{A}}$ and $\mathrm{SBR}_{\mathrm{B}}$

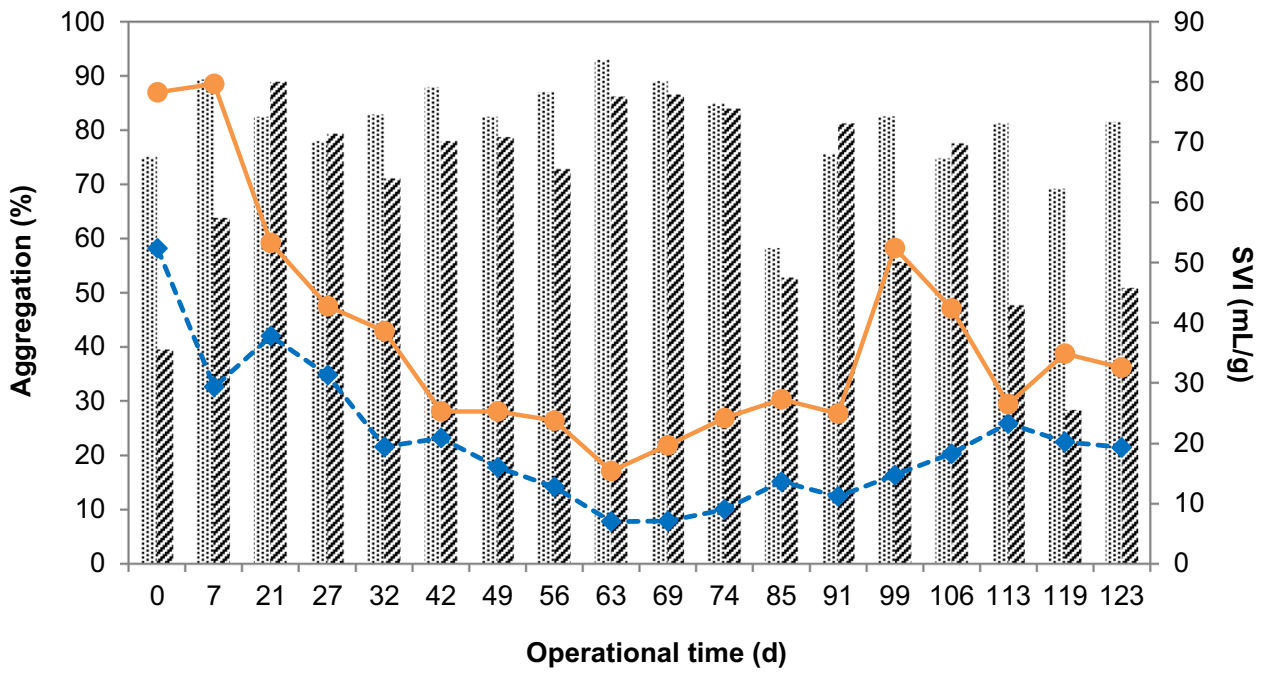

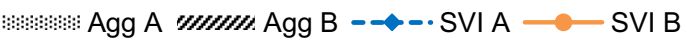


compared to $\mathrm{SBR}_{\mathrm{B}}$, which obtained average SVI of $31 \mathrm{~mL} / \mathrm{g}$. The significant difference between $\mathrm{SBR}_{\mathrm{A}}$ and $\mathrm{SBR}_{\mathrm{B}}$ can be explained in terms of the magnetic field effect in improving the collision among the biomass. As shown in Fig. 2, $\mathrm{SBR}_{\mathrm{A}}$ exhibited higher MLSS concentration compared to $\mathrm{SBR}_{\mathrm{B}}$. High biomass in the reactor produced high chance of collisions, thus allowing aggregation to occur rapidly. Implementation of magnetic field in $\mathrm{SBR}_{\mathrm{A}}$ may initiate a triggering process, which releases or redirects ordinary metabolic energy to produce certain biological effects (Wang et al. 2012; Zaidi et al. 2019a). In this case, magnetic field might be able to influence the EPS production by microorganisms that present in $\mathrm{SBR}_{\mathrm{A}}$. EPS can bind cells closely through ion bridging interactions, hydrophobic interactions, and polymer entanglement, which serve to enhance and promote aggregation (Tsuneda et al. 2003; Sheng et al. 2010). Consequently, this occurrence resulted in low SVI. This indicates better settleability of biomass in $\mathrm{SBR}_{\mathrm{A}}$ compared to $\mathrm{SBR}_{\mathrm{B}}$.

Nevertheless, throughout the experimental period, the lowest aggregation of biomass in $\mathrm{SBR}_{\mathrm{A}}$ was occurred at day 85 with percentage of $58 \%$. The sudden reduction occurred could be due to the more production of loosely bound EPS (LB-EPS). LB-EPS is a loose and dispersible slime layer without an obvious edge. However, the effect of magnetic field was now known to able in influencing the EPS production (Wang et al. 2012; Zaidi et al. 2019a), but whether the effect is more toward producing LB-EPS more than TB-EPS or vice versa has not yet been elucidated. Increase in LB-EPS content may bring more bound water into the aggregates and therefore produce highly porous flocs with a low density (Yang and Li 2009; Sheng et al. 2010). Consequently, this occurrence inhibited the aggregation process, thus causing slight increase in SVI for $\mathrm{SBR}_{\mathrm{A}}$.
As for $\mathrm{SBR}_{\mathrm{B}}$, fluctuation in aggregation was continuously observed throughout the experimental period. This could be due to the proliferation of filamentous microorganisms that might have taken place in the activated sludge of $\mathrm{SBR}_{\mathrm{B}}$ due to condition of low DO concentration. The filaments could protrude faster over the flocs due to their morphology characteristics and could cause the aggregation to hardly occur (Martins et al. 2003; Guo et al. 2014; Zaidi et al. 2019b). This has then further reduced the settleability where the SVI was higher in this reactor compared to $\mathrm{SBR}_{\mathrm{A}}$.

\section{Effect of magnetic field on relative hydrophobicity and surface charge of biomass under low DO condition}

Figure 4 shows the profile of relative hydrophobicity and surface charge of biomass for $\mathrm{SBR}_{\mathrm{A}}$ and $\mathrm{SBR}_{\mathrm{B}}$ over the experimental period. These two parameters are inversely correlated within each other and commonly related to the settleability of the biomass. Previous studies indicate that changes in relative hydrophobicity are affected by many factors that cause stress to the systems such as starvation of the microorganisms, the growth rate, substrate, $\mathrm{pH}$ and temperature (Liu et al. 2004; Sheng et al. 2010; Wang et al. 2012). In this study, application of magnetic field in $\mathrm{SBR}_{\mathrm{A}}$ may exhibit certain stressful effects to the microorganisms that present in the system. This condition has then allowed the microorganisms to exhibit EPS that may contain lipids, nucleic acids, and some inorganic components. Due to the high production of lipid contained in EPS, the microorganisms would become more hydrophobic and in turn strengthen the cellto-cell interaction of a microbial structure. This could be a fair explanation that reasoned the comparison of the relative hydrophobicity between $\mathrm{SBR}_{\mathrm{A}}$ and $\mathrm{SBR}_{\mathrm{B}}$ upon which $\mathrm{SBR}_{\mathrm{A}}$
Fig. 4 Relative hydrophobicity (RH) and surface charge (SC) profiles of biomass for $\mathrm{SBR}_{\mathrm{A}}$ and $\mathrm{SBR}_{\mathrm{B}}$

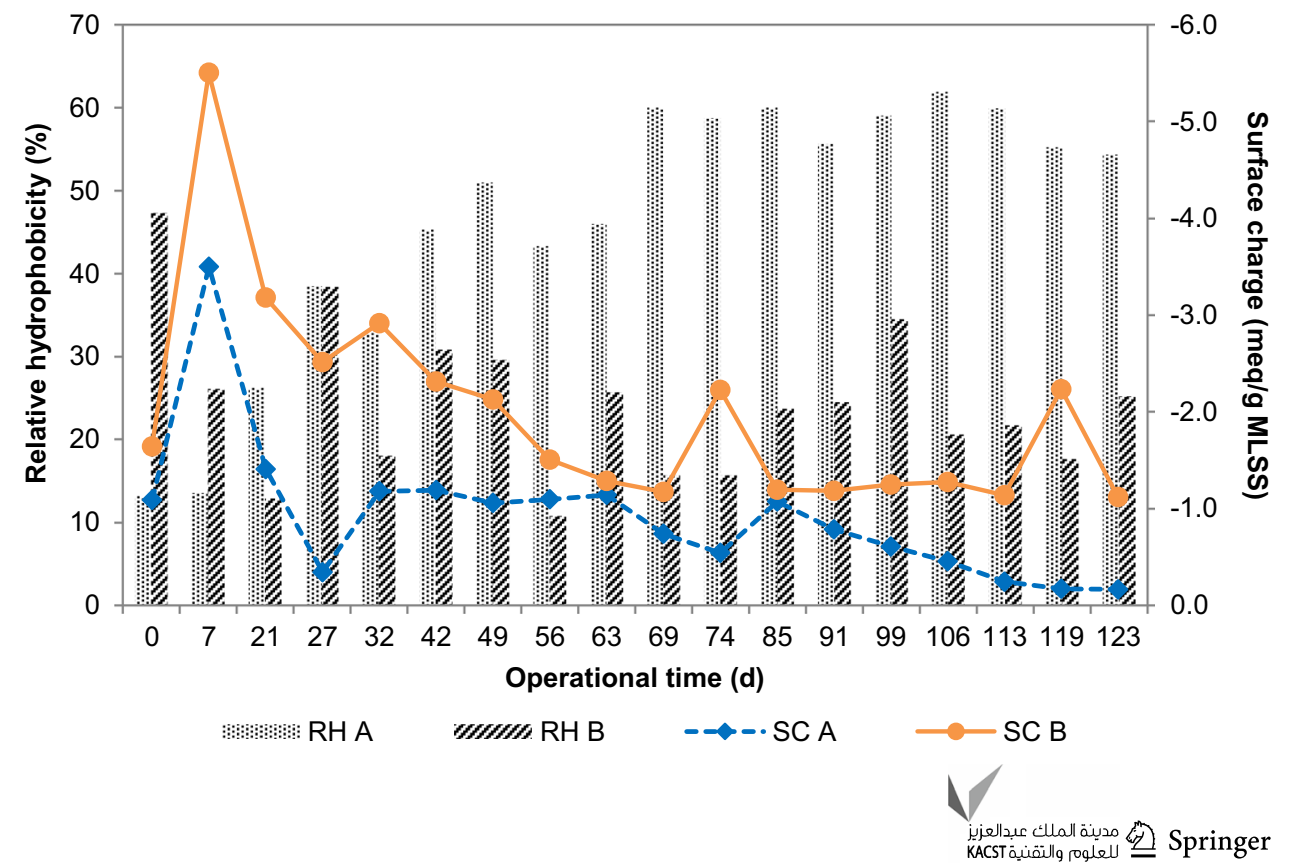


showed high hydrophobicity of average $57 \%$ compared to $\mathrm{SBR}_{\mathrm{B}}$ with almost half of the $\mathrm{SBR}_{\mathrm{A}}$ 's average percentage.

During the initial stage of the experiment (i.e., day 0 to day 7), contrast observation was obtained at which $\mathrm{SBR}_{B}$ possessed high relative hydrophobicity compared to $\mathrm{SBR}_{\mathrm{A}}$. Such occurrence could be due to the less adaptation of the activated sludge toward the magnetic field effect. Based on the principle of magnetic memory, repetitive exposure of the magnetic field on the media (i.e., biomass) can only favor optimum effect of the magnetic field (Colic and Morse 1999; Johan 2003). Early state of the experiment may not provide enough time for the biomass in $\mathrm{SBR}_{\mathrm{A}}$ to be repeatedly exposure by the magnetic field. It thus caused low percentage of relative hydrophobicity in the reactor.

For the surface charge of the biomass, it has been related in various ways to both flocculation and bulking. The presence of a net negative surface charge on floc surfaces may create repulsive electrostatic interactions, which prevents close contact between particles. A high value of negative surface charge indicates that there may be more free negative charges and less electrostatic binding of cations on the surfaces of the sludge flocs. Jin et al. (2003) hypothesized that if the negative surface charge is high they will repel each other more and thereby keeping the flocs in a more expanded state. Based on Fig. $4, \mathrm{SBR}_{\mathrm{A}}$ showed lower negative surface charge compared to $\mathrm{SBR}_{\mathrm{B}}$. The mean surface charge for $\mathrm{SBR}_{\mathrm{A}}$ was -0.9 meq/g MLSS while for $\mathrm{SBR}_{\mathrm{B}}$ was $-2.0 \mathrm{meq} / \mathrm{g}$ MLSS. These values, however, can be considered high as compared to the common range of surface charge values for the biomass under normal condition. This is suggesting that the unusual condition which been induced by low DO concentration that consequently led to the occurrence of sludge bulking may have caused disturbance to the adhesion and settleability of the biomass (Thompson and Forster 2003; Zaidi et al. 2019b).
At day 7 (as shown in 4), both reactors were observed having high negative surface charge by $-3.5 \mathrm{meq} / \mathrm{g}$ MLSS for $\mathrm{SBR}_{\mathrm{A}}$ and $-5.5 \mathrm{meq} / \mathrm{g}$ MLSS for $\mathrm{SBR}_{\mathrm{B}}$. The sudden increase could be due to the presence of filamentous microorganisms as the condition of DO concentration was set lowered. The filamentous microorganisms may tend to protrude the sludge flocs, thus resulting in larger surface area. In this study, the measurement of surface charge adopted the method that based on adsorption of cationic polymers to the sludge surface. The measured surface charge could be highly affected by the larger sludge surface area of the flocs produced by the filaments (Mikkelsen and Keiding 2002; Jin et al. 2003). This has then resulted in the high measurement of the surface charge for the samples of that respective day. The surface charge for $\mathrm{SBR}_{\mathrm{A}}$ was gradually decreased then and remained consistent throughout the experiment, while alternate increase and decrease profile of negative surface charge was still observed in $\mathrm{SBR}_{\mathrm{B}}$.

\section{Effect of magnetic field under low DO condition on the removal of COD}

The comparison of COD removal performance between $\mathrm{SBR}_{\mathrm{A}}$ and $\mathrm{SBR}_{\mathrm{B}}$ is given in Fig. 5. Initially, the removal for $\mathrm{SBR}_{\mathrm{A}}$ and $\mathrm{SBR}_{\mathrm{B}}$ was $80 \%$ and $71 \%$, respectively. The removal efficiency has then increased to $88 \%$ for $\mathrm{SBR}_{\mathrm{A}}$ but decreased to $69 \%$ for $\mathrm{SBR}_{\mathrm{B}}$ at the end of the experiment. The increase in the removal efficiency as has been observed in $\mathrm{SBR}_{\mathrm{A}}$ indicates the occurrence of high biological activity in the reactor system. This projection was consistent with the results reported by researchers conveyed that the magnetic field has an effect in enhancing the biological activity in the wastewater treatment (Ji et al. 2010; Łebkowska et al. 2011; Křriklavová et al. 2014; Omar et al. 2018).
Fig. 5 Profile of COD removal for $\mathrm{SBR}_{\mathrm{A}}$ and $\mathrm{SBR}_{\mathrm{B}}$ over the experimental period

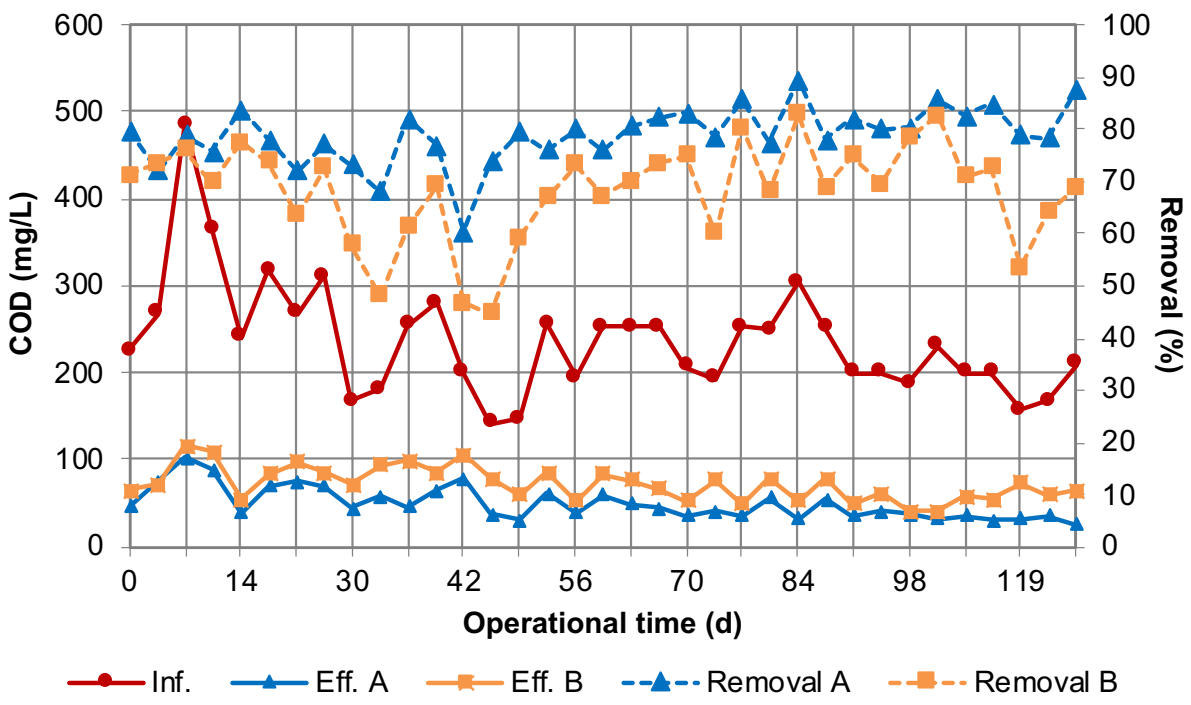


Maximum COD removal for both reactors was observed at day 84 , which was $90 \%$ for $\mathrm{SBR}_{\mathrm{A}}$ and $83 \%$ for $\mathrm{SBR}_{\mathrm{B}}$. This observation can be considered as an important contribution of the magnetic field at $88.0 \mathrm{mT}$ applied in $\mathrm{SBR}_{\mathrm{A}}$ on the COD removal. Application of the magnetic field might increase the microorganisms' growth, thus resulting in the enhancement of the removal despite the possible occurrence of the sludge bulking due to low DO concentration.

At day onwards, a slight drop of COD removal was observed in $\mathrm{SBR}_{\mathrm{A}}$ (with mean of $82 \pm 3 \%$ ), while a great drop was observed in $\mathrm{SBR}_{\mathrm{B}}$ (with mean of $70 \pm 8 \%$ ). Significant and continuous drop occurred in $\mathrm{SBR}_{\mathrm{B}}$, suggesting that the sludge might have been dominated by the proliferation of filamentous microorganisms. This is because the filamentous microorganisms have a greater tolerance of low DO levels than the floc-forming bacteria. At continuous low DO concentrations, filamentous microorganisms could actively proliferate as their relative biomass increases, thus limiting the growth and activity of aerobic microorganisms to biodegrade the COD (Martins et al. 2004; Davies 2005; Guo et al. 2014). Meanwhile in $\mathrm{SBR}_{\mathrm{A}}$, the reduction of COD removal toward the end of the experiment was lower and maintained its high value compared to $\mathrm{SBR}_{\mathrm{B}}$. Krriklavová et al. (2014) conveyed that the magnetic field has the capability of improving the enzyme activity and physiological reaction activity of the microorganisms, thus at once improve the utilizing ability of these microorganisms in removing the COD.

\section{Effect of magnetic field under low DO condition on the removal of ammonia-nitrogen $\left(\mathrm{NH}_{4}-\mathrm{N}\right)$}

The profile for $\mathrm{NH}_{4}-\mathrm{N}$ concentration in the influent, effluent and removal performances for both reactors throughout the experiment is given in Fig. 6. Overall, the magnetically exposed activated sludge system $\left(\mathrm{SBR}_{\mathrm{A}}\right)$ showed consistently higher removal compared to $\mathrm{SBR}_{\mathrm{B}}$. During early stage of the experiment, higher removal was observed in $\mathrm{SBR}_{\mathrm{B}}$ rather than in $\mathrm{SBR}_{\mathrm{A}}$, indicating that the system has not being stable yet. Starting at day $8, \mathrm{SBR}_{\mathrm{A}}$ took place of high removal compared to $\mathrm{SBR}_{\mathrm{B}}$ until the end of experiment. Overall, the average removal for $\mathrm{SBR}_{\mathrm{A}}$ was $80 \pm 2 \%$ while for $\mathrm{SBR}_{\mathrm{B}}$ was $74 \pm 3 \%$.

Although the reactors were aggravated by low DO condition in order to induce the sludge bulking symptom, $\mathrm{SBR}_{\mathrm{A}}$ which under the application of magnetic field was able to maintain high removal of $\mathrm{NH}_{4}-\mathrm{N}$. This observation support the theory that the magnetic field has an effect in enhancing the biological activity, and as in this case the magnetic field has the influence on the ammonium oxidizing bacteria (AOB) (Liu et al. 2008; Wang et al. 2012). The positive influence on $\mathrm{AOB}$ improved the degradation activity of influent $\mathrm{NH}_{4}-\mathrm{N}$ concentration, thus resulting in low effluent concentration and high percentage removal in $\mathrm{SBR}_{\mathrm{A}}$.

As shown in Fig. 6, rapid fluctuation of the removal for both reactors was also observed. These observations suggested that the unstable amount of biomass loss in the effluent could be occurred during the treatment process. The loss of biomass may reduce the presence of aerobic microorganisms that are beneficial in degrading the $\mathrm{NH}_{4}-\mathrm{N}$. This had thus resulting in inefficient removal of $\mathrm{NH}_{4}-\mathrm{N}$ for both reactors. Although the removal trend showed the fluctuating profile, $\mathrm{SBR}_{\mathrm{A}}$ was able to keep its high removal performance compared to $\mathrm{SBR}_{\mathrm{B}}$. Toward the end of the experiment, the ability of $\mathrm{SBR}_{\mathrm{A}}$ which under the exposure of magnetic field to remove $\mathrm{NH}_{4}-\mathrm{N}$ gradually increased, reaching the removal efficiency of $78 \%$ with the effluent reduced to $4 \mathrm{mg} / \mathrm{L}$.
Fig. 6 Profile of $\mathrm{NH}_{4}-\mathrm{N}$ removal between $\mathrm{SBR}_{\mathrm{A}}$ and $\mathrm{SBR}_{\mathrm{B}}$ over the experimental period

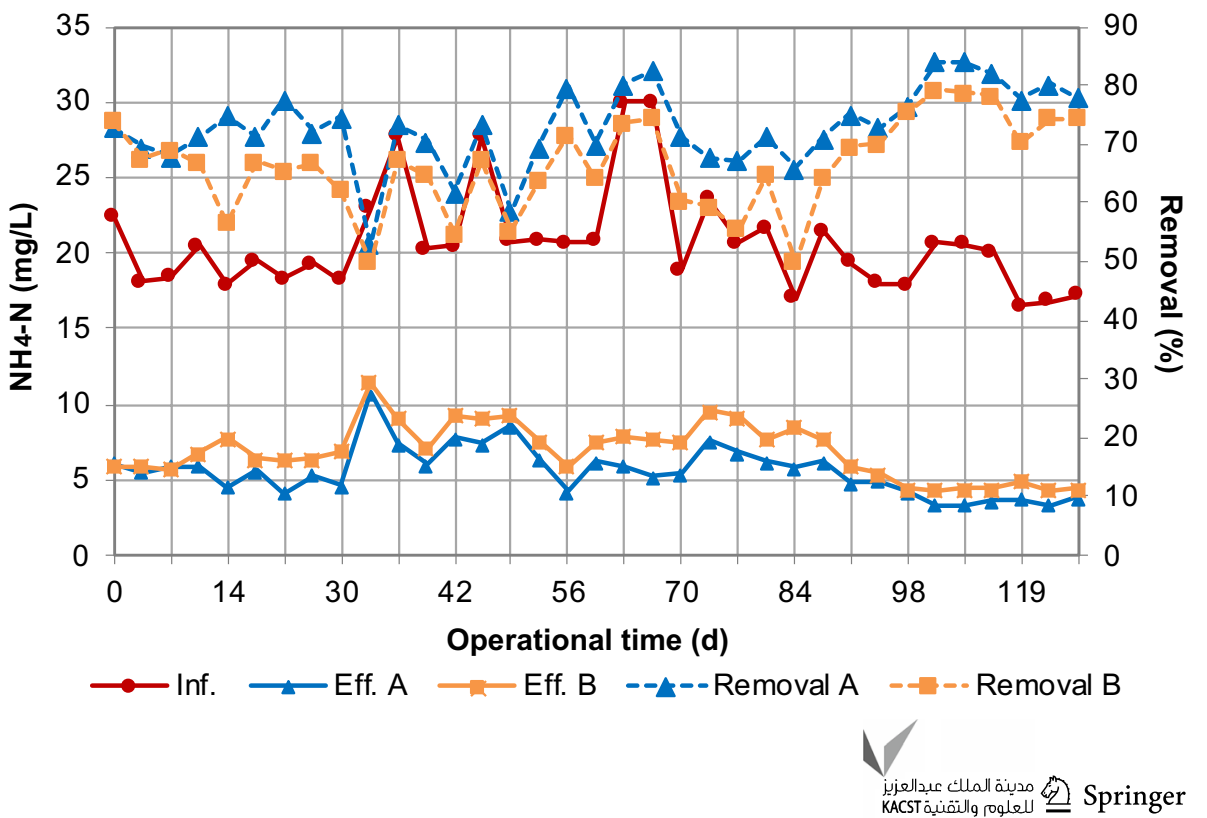


Fig. 7 Profile of influent-effluent nitrite concentration for $\mathrm{SBR}_{\mathrm{A}}$ and $\mathrm{SBR}_{\mathrm{B}}$
Fig. 8 Profile of influent-effluent nitrate concentrations for $\mathrm{SBR}_{\mathrm{A}}$ and $\mathrm{SBR}_{\mathrm{B}}$
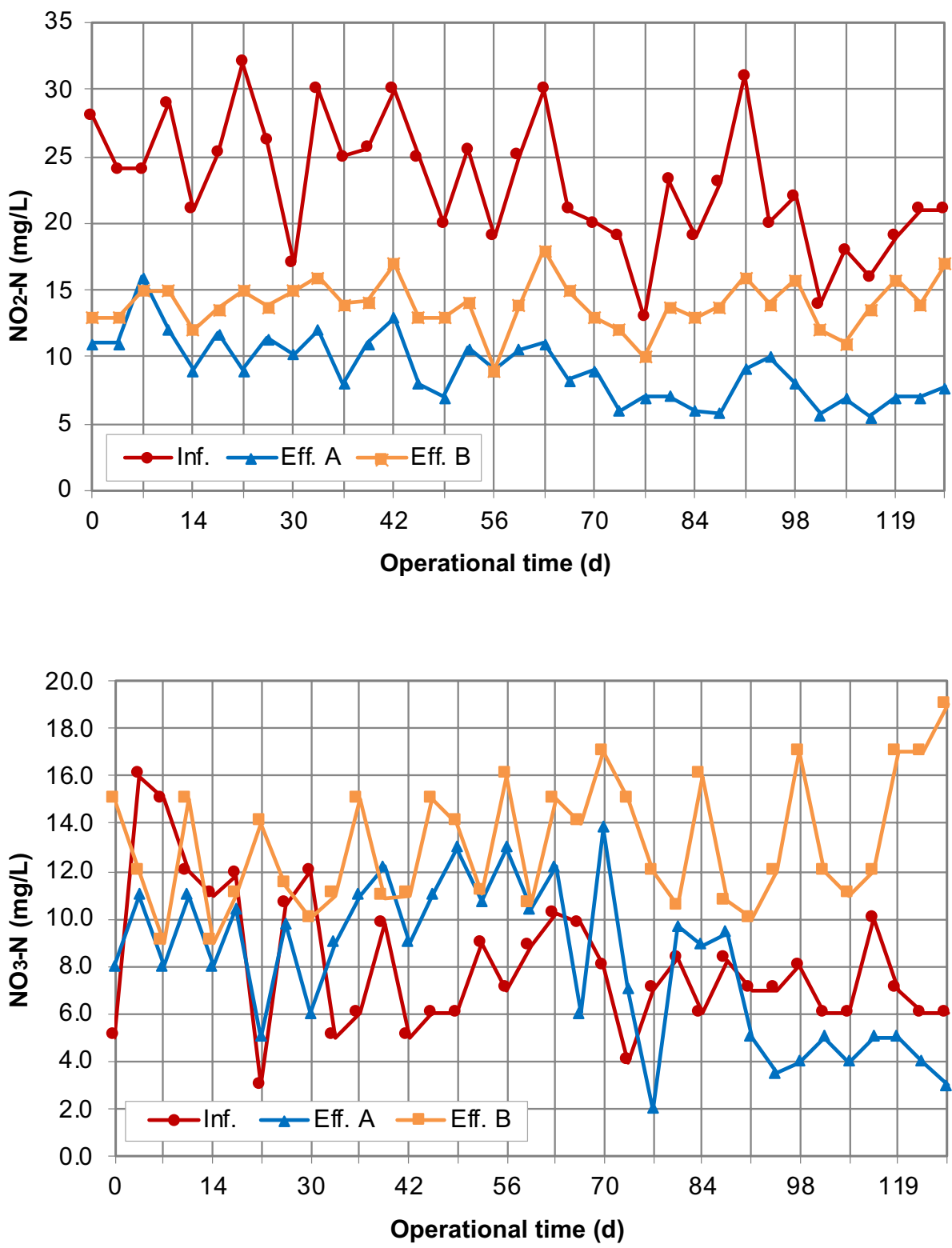

\section{Effect of magnetic field under low DO condition on the removal of nitrogen}

The variation of nitrogen, which are nitrite and nitrate in $\mathrm{SBR}_{\mathrm{A}}$ and $\mathrm{SBR}_{\mathrm{B}}$, is shown in Figs. 7 and 8, respectively. As these experiments were conducted under low DO concentration of ranged between 0.5 to $2.0 \mathrm{mg} / \mathrm{L}$, these experiments can be considered as conducted under anoxic condition. According to Jenkins et al. (2004), anoxic condition is a favorable condition for filamentous microorganisms to grow. Hence, this condition is one of the suitable states to be conducted in order to study the sludge bulking occurrence and its consequent on the removal of nitrogen.

Based on Fig. 7, the nitrite removal for $\mathrm{SBR}_{\mathrm{A}}$ was fairly high compared to $\mathrm{SBR}_{\mathrm{B}}$. On average, the nitrite removal for $\mathrm{SBR}_{\mathrm{A}}$ was $65 \pm 2 \%$ while for $\mathrm{SBR}_{\mathrm{B}}$ was $21 \pm 8 \%$. The consistency of low effluent nitrite concentration was also greatly indicated by $\mathrm{SBR}_{\mathrm{A}}$ compared to $\mathrm{SBR}_{\mathrm{B}}$. On average, the effluent nitrite concentration for $\mathrm{SBR}_{\mathrm{A}}$ throughout the experimental period was $7 \pm 1 \mathrm{mg} / \mathrm{L}$ while for $\mathrm{SBR}_{\mathrm{B}}$ was $15 \pm 2 \mathrm{mg} / \mathrm{L}$. Ideally, nitrite is produced through oxidization of $\mathrm{NH}_{4}-\mathrm{N}$ by Nitrosomonas and being removed by Nitrobacter into nitrate (Davies 2005). In this study, low effluent concentration of nitrite in $\mathrm{SBR}_{\mathrm{A}}$ strengthens the theories that the magnetic field is potential in enhancing the growth and activity of nitrifying bacteria, thus allowing it to undergo effective nitrification process (Tomska and Wolny 2008; Wang et al. 2012). In contrast, the efficiency of nitrite removal in $\mathrm{SBR}_{\mathrm{B}}$ was lower and could be due to the situation that the nitrifying bacteria may be out-competed with 
the proliferated filamentous microorganisms. This had thus limited the activity of nitrifying bacteria and jeopardized the nitrification process. Hence, it resulted in higher effluent concentration and lower percentage of removal.

Figure 7 also shows severe fluctuation of nitrite's removal that occurred in $\mathrm{SBR}_{\mathrm{B}}$. Despite the inconsistent concentration of nitrite's influent, which may contribute to such observation, it can also be due to the oxygen deficiency condition. Theoretically, oxidization of nitrite into nitrate required sufficient source of oxygen. However, in this experimental condition, low dissolved oxygen was set in order to induce sludge bulking symptom. Consequently, this condition affected the oxidization process, thus resulting in ups and downs of the nitrite removal efficiency in $\mathrm{SBR}_{\mathrm{B}}$. Different than in $\mathrm{SBR}_{\mathrm{A}}$, which was influenced by magnetic field, the removal efficiency could be maintained almost consistent with less fluctuation occurred.

For the nitrate component, the overall results indicated that slightly lower concentration of nitrate in the effluent released by $\mathrm{SBR}_{\mathrm{A}}$ compared to $\mathrm{SBR}_{\mathrm{B}}$ (Fig. 8). On average, the effluent concentration for $\mathrm{SBR}_{\mathrm{A}}$ was $4 \pm 1 \mathrm{mg} / \mathrm{L}$ while for $\mathrm{SBR}_{\mathrm{B}}$ was $18 \pm 1 \mathrm{mg} / \mathrm{L}$. However, the consistency of the nitrate's removal was negative. This is because throughout the experimental period, the production of nitrate was also occurred in both reactors. Based on Fig. 8, the nitrate's productions in $\mathrm{SBR}_{\mathrm{A}}$ were fluctuated from starting of the experiment until at about day 84 . After reached day 86 , the effluent concentration started to be lower than the influent concentration, thus resulting in almost consistent nitrate's removal. Meanwhile, in $\mathrm{SBR}_{\mathrm{B}}$, the nitrate's productions were dominated throughout the experimental period. This could be due to the failure of denitrification process.

Although the system was set at low DO concentration, which supposed can help in denitrification process, $\mathrm{SBR}_{\mathrm{B}}$ failed to attain such condition. This may be due to the lack of responsible denitrifying bacteria, which is heterotrophic bacteria (Nielson et al. 2004; Hwang et al. 2005). These heterotrophic bacteria may be washed-out during decanting phase, hence leaving only a small group of bacteria to denitrify the nitrate. Such explanation can also be supported by the results of biomass concentration at which low biomass was retained in $\mathrm{SBR}_{\mathrm{B}}$ compared to in $\mathrm{SBR}_{\mathrm{A}}$ (Table 1). Consequently, inefficient denitrification process cannot take place in $\mathrm{SBR}_{\mathrm{B}}$; thus, great concentration of oxidized nitrate (produced from the nitrification process) was then remained in the treated effluent.

\section{Effect of magnetic field under low DO condition on the removal of phosphorus}

The phosphorus removal efficiency under limited filamentous sludge bulking (due to low DO concentration) was investigated, as shown in Fig. 9. Briefly, there were significant differences between the removal of phosphorus for $\mathrm{SBR}_{\mathrm{A}}$ and $\mathrm{SBR}_{\mathrm{B}}$. Overall, the performances indicated that $\mathrm{SBR}_{\mathrm{A}}$ obtained higher removal efficiency compared to control $\mathrm{SBR}_{\mathrm{B}}$ throughout the experimental period.

Under low DO concentration, the decrease removal of phosphorus is anticipated. This is because low DO concentration favored the growth of most filamentous microorganisms species. According to Cydzik-Kwiatkowska and Zielińska (2016), when the biomass was abundant with filamentous microorganisms, there will be a tendency of microbial shifting between filamentous microorganisms and phosphorus accumulating organisms (PAOs) that are responsible in removing phosphorus. Due to this microbial shifting, there could be a chance that PAOs acted more like filamentous microorganisms, thus may not involve in biodegradation
Fig. 9 Profile of influent-effluent phosphorus concentration for $\mathrm{SBR}_{\mathrm{A}}$ and $\mathrm{SBR}_{\mathrm{B}}$
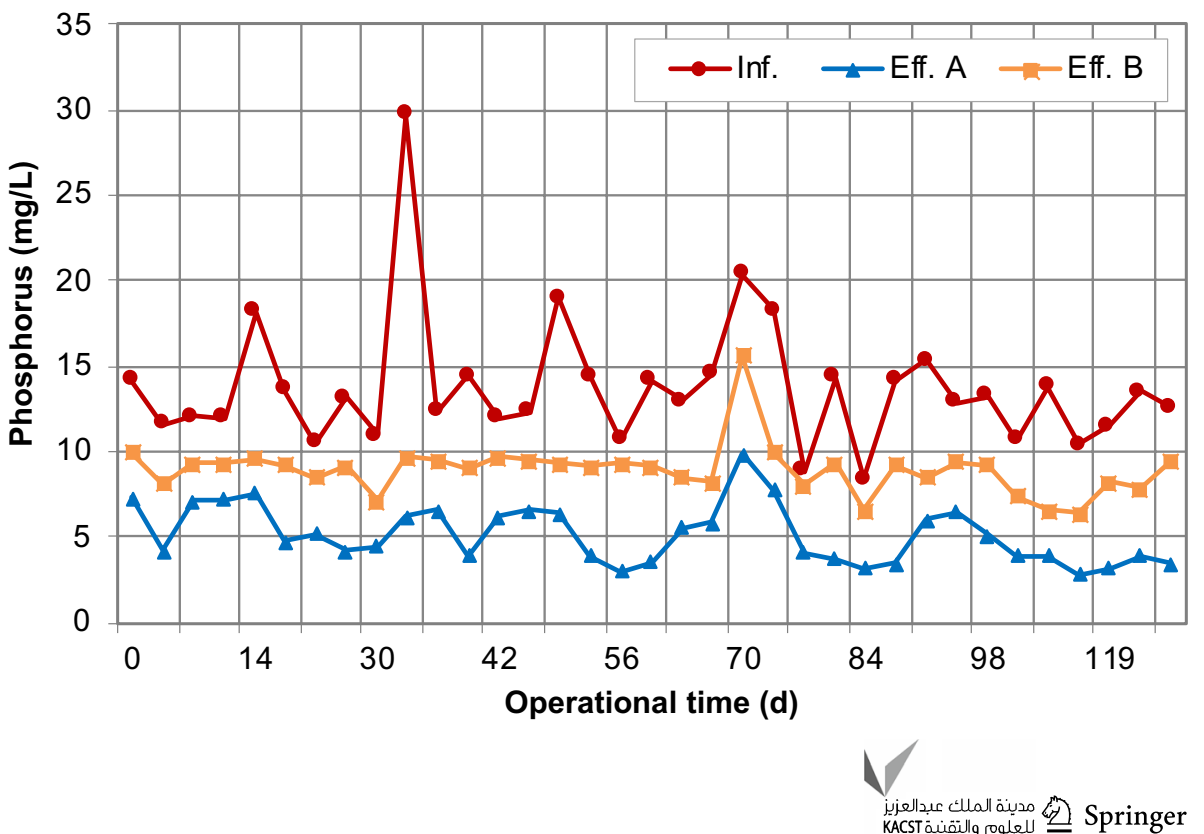
of the phosphorus. As a result, less removal of phosphorus was observed such as shown in $\mathrm{SBR}_{\mathrm{B}}$. However, for $\mathrm{SBR}_{\mathrm{A}}$, the removal of phosphorus can still be high even under circumstances of low DO concentration, which could be due to the implementation of magnetic field.

On average, the removal of phosphorus for $\mathrm{SBR}_{\mathrm{A}}$ throughout the experimental period was $72 \pm 1 \%$ while for $\mathrm{SBR}_{\mathrm{B}}$ was $37 \pm 11 \%$. The influent phosphorus concentration with an average value of $12 \mathrm{mg} / \mathrm{L}$ fluctuated between 8 and $30 \mathrm{mg} / \mathrm{L}$, while effluent concentrations with an average value of $4 \mathrm{mg} / \mathrm{L}$ for $\mathrm{SBR}_{\mathrm{A}}$ and $8 \mathrm{mg} / \mathrm{L}$ for $\mathrm{SBR}_{\mathrm{B}}$ were also obtained. High removal efficiency and low effluent concentration indicated by $\mathrm{SBR}_{\mathrm{A}}$ can be explained due to the effect of $88.0 \mathrm{mT}$ magnetic field intensity in enhancing the enzymatic activity of PAOs. Such enhancement might able to improve the removal efficiency in the reactor despite the condition of low DO level. Ishiwata et al. (2010) also agreed on the positive effect exhibited by the magnetic field in enhancing the phosphorus removal. Contrary, continuous low removal efficiency in $\mathrm{SBR}_{\mathrm{B}}$ was due to the deficient supply of oxygen during the treatment process. Lack of oxygen may aborted the growth of PAOs, thus impeded the removal of phosphorus. Throughout the experiment, a sudden increase of removal was notable in both reactors which at day 34 by $79 \%\left(\mathrm{SBR}_{\mathrm{A}}\right)$ and $67 \%\left(\mathrm{SBR}_{\mathrm{B}}\right)$. This was due to the drastic influent loading in the used raw wastewater that eventually resulted in the maximum increase of the phosphorus accumulation by PAOs.

Nevertheless, the removal efficiency under the effect of magnetic field (as in $\mathrm{SBR}_{\mathrm{A}}$ ) was quite low, which is less than $80 \%$. Such observation can be reasoned in terms of the use of magnetic field at which its intensity may not sufficiently high in accelerating the enzymatic activity of PAOs. Various types of microorganisms may have their unique susceptibility including PAOs (Zaidi et al. 2019b). Therefore, higher magnetic field intensity could be possible in enhancing the PAOs' activity, and in turn exhibited high removal efficiency. Ishiwata et al. (2010) evidenced that the implementation of high magnetic field intensity (i.e., $1 \mathrm{~T}$ ) had reduced the effluent phosphorus concentration to as low as $0.03 \mathrm{mg} / \mathrm{L}$.

\section{Conclusion}

1. The MLSS and MLVSS in $\mathrm{SBR}_{\mathrm{A}}$ were generally higher than $\mathrm{SBR}_{\mathrm{B}}$. Therefore, the obtained ratio of MLVSS/ MLSS was higher in $\mathrm{SBR}_{\mathrm{A}}$ compared to $\mathrm{SBR}_{\mathrm{B}}$. Consequently, these observations resulted in low effluent suspended solids for $\mathrm{SBR}_{\mathrm{A}}$ compared to $\mathrm{SBR}_{\mathrm{B}}$.

2. The mean SRT of the reactor system was $12.3 \pm 0.2$ day for $\mathrm{SBR}_{\mathrm{A}}$ and $11.5 \pm 0.8$ day for $\mathrm{SBR}_{\mathrm{B}}$, indicating that both reactors are potential of $\mathrm{COD}$ and nitrification process.
3. High biomass concentration in $\mathrm{SBR}_{\mathrm{A}}$ was resulted to low $\mathrm{SVI}$ compared to $\mathrm{SBR}_{\mathrm{B}}$. Biomass in $\mathrm{SBR}_{\mathrm{A}}$ was also exhibited high aggregation and relative hydrophobicity compared to $\mathrm{SBR}_{\mathrm{B}}$. In terms of surface charge, biomass in $\mathrm{SBR}_{\mathrm{A}}$ showed less negative charged compared to biomass in $\mathrm{SBR}_{\mathrm{B}}$. These observations imply that the magnetic field of intensity $88.0 \mathrm{mT}$ was able to enhance the physical properties of the biomass under the probable adverse effect of low DO concentration. Consequently, this indicated that the sludge bulking could be mitigated by the magnetic field.

4. $\mathrm{SBR}_{\mathrm{A}}$ showed consistent high $\mathrm{COD}, \mathrm{NH}_{4}-\mathrm{N}$, nitrite and phosphorus removal performances compared to $\mathrm{SBR}_{\mathrm{B}}$. These observations imply that the application of magnetic field was able to enhance the metabolism activity and biodegradation ability of the aerobic bacteria even under low DO concentration. This also indicates that under the sludge bulking circumstances, the use of magnetic field stands a great chance in maintaining high and efficient removal ability of the treatment system.

Funding The research was financed to KM by the Ministry of Higher Education (MOHE) under Fundamental Research Grant Scheme (FRGS) via Grant Vot. No. 4F984.

\section{Compliance with ethical standards}

Conflict of interest The authors declare no conflict of interest.

Open Access This article is licensed under a Creative Commons Attribution 4.0 International License, which permits use, sharing, adaptation, distribution and reproduction in any medium or format, as long as you give appropriate credit to the original author(s) and the source, provide a link to the Creative Commons licence, and indicate if changes were made. The images or other third party material in this article are included in the article's Creative Commons licence, unless indicated otherwise in a credit line to the material. If material is not included in the article's Creative Commons licence and your intended use is not permitted by statutory regulation or exceeds the permitted use, you will need to obtain permission directly from the copyright holder. To view a copy of this licence, visit http://creativecommons.org/licenses/by/4.0/.

\section{References}

American Public Health Association (2005) Standard methods for the examination of water and wastewater, 21th ed. Washington DC, USA

Chang I-S, Lee C-H (1998) Membrane filtration characteristics in membrane-coupled activated sludge system - the effect of physiological states of activated sludge on membrane fouling. Desalination 120(3):221-233. https://doi.org/10.1016/S0011-9164(98) 00220-3

Colic M, Morse D (1999) The elusive mechanism of the magnetic 'memory' of water. Colloids Surf A 154(1-2):167-174 
Cydzik-Kwiatkowska A, Zielińska M (2016) Bacterial communities in full scale wastewater treatment systems. World J Microbiol Biotechnol 32(66):1-8

Davies PS (2005) The biological basis of wastewater treatment. Strathkelvin Instruments Ltd., Glasgow

Deepnarain N, Kumari S, Ramjith J, Swalaha FM, Tandoi VK, Bux PF (2015) A logistic model for the remediation of filamentous bulking in a biological nutrient removal wastewater treatment plant. Water Sci Technol 72(3):391-405

Du B, Wang R, Yang Q, Hu H, Li X, Duan X (2018) Impact of tetracycline on the performance and abundance of functional bacteria of a lab-scale anaerobic- aerobic wastewater treatment system. Biochem Eng J 138:98-105

Durban N, Juzan L, Krier J, Gillot S (2016) Control of Microthrix parvicella by aluminium salts addition. Water Sci Technol 73(2):414-422

Fan N, Wang R, Qi R, Gao Y, Rossetti S, Tandoi V, Yang M (2018) Control strategy for filamentous sludge bulking: bench-scale test and full-scale application. Chemosphere 210:709-716

Filipič J, Kraigher B, Tepuš B, Kokol V, Mandic-Mulec I (2012) Effects of low-density static magnetic fields on the growth and activities of wastewater bacteria Escherichia coli and Pseudomonas putida. Biores Technol 120:225-232

Guo J, Wang S, Wang Z, Peng Y (2014) Effects of feeding pattern and dissolved oxygen concentration on microbial morphology and community structure: the competition between floc-forming bacteria and filamentous bacteria. J Water Process Eng 1:108-114

Hwang Y, Kim C, Choo I (2005) Simultaneous nitrification/denitrification in a single reactor using ciliated columns packed with granular sulfur. Water Qual Res J Can 40:91-96

Ishiwata T, Miura O, Hosomi K, Shimizu K, Ito D, Yoda Y (2010) Removal and recovery of phosphorus in wastewater by superconducting high gradient magnetic separation with ferromagnetic adsorbent. Physica C 470:1818-1821

Jenkins D, Richard MG, Daigger GT (2004) Manual on the cause and control of activated sludge bulking, foaming and other solids separation problems, 3rd edn. Lewis Publishers, Chelsea

Ji Y, Wang Y, Sun J, Yan T, Li J, Zhao T, Yin X, Sun C (2010) Enhancement of biological treatment of wastewater by magnetic field. Bioresour Technol 101:8535-8540

Jin B, Wilén B-M, Lant P (2003) A comprehensive insight into floc characteristics and their impact on compressibility and settleability of activated sludge. Chem Eng J 95:221-234

Johan S (2003) Effect of magnetic field on the sedimentation of suspended solids of sewage. Thesis of philosophy of doctorate, UniversitiTeknologi Malaysia, Skudai

Křiklavová L, Truhlář M, Škodová P, Lederer T, Jirků V (2014) Effects of a static magnetic field on phenol degradation effectiveness and Rhodococcus erythropolis growth and respiration in a fed-batch reactor. Bioresour Technol 167:510-513

Łebkowska M, Rutkowska-Narożniak A, Pajor E, Pochanke Z (2011) Effect of a static magnetic field on formaldehyde biodegradation in wastewater by activated sludge. Bioresour Technol 102(19):8777-8782

Liu Y, Yang SF, Tay JH, Liu QS, Qin L, Li Y (2004) Cell hydrophobicity is a triggering force of biogranulation. Enzyme Microb Technol 34:371-379

Liu S, Yang F, Meng F, Chen H, Gong Z (2008) Enhanced anammox consortium activity for nitrogen removal: impacts of static magnetic field. J Biotechnol 138(3-4):96-102

Martins AMP, Van Loosdrecht MCM, Heijnen JJ (2003) Effect of feeding pattern and storage on the sludge settleability under aerobic conditions. Water Res 37(11):2555-2570

Martins AMP, Pagilla K, Heijnen JJ, Van Loosdrecht MCM (2004) Filamentous bulking sludge—a review. Water Res 38:793-817
Mikkelsen LH, Keiding K (2002) Physico-chemical characteristics of full scale sewage sludge with implications to dewatering. Water Res 36(10):2451-2462

Morgan JW, Forster CF, Evison L (1990) A comparative study of the nature of biopolymers extracted from anaerobic and activated sludges. Water Res 24(6):743-750. https://doi.org/10.1016/00431354(90)90030-A

Nielson PH, Thompson TR, Nielson JL (2004) Bacterial composition of activated sludge-importance for floc and sludge properties. Water Sci Technol 49:51-58

Nittami T, Shoji T, Koshiba Y, Noguchi M, Oshiki M, Kuroda M, Kindaichi T, Fukuda J, Kurisu F (2019) Investigation of prospective factors that control Kouleothrix (Type 1851) filamentous bacterial abundance and their correlation with sludge settleability in full-scale wastewater treatment plants. Process Saf Environ Prot 124:137-142

Noutsopoulos C, Mamais D, Andreadakis A (2010) Long chain fatty acids removal in selector tanks: evidence for insufficient Microthrix parvicella control. Desalin Water Treat 23(1-3):20-25

Oka T, Kanayama H, Tanaka K, Fukui S, Ogawa J, Sato T, Ooizumi M, Terasawa T, Itoh Y, Yabuno R (2009) Waste water purification by magnetic separation technique using HTS bulk magnet system. Physica C 469(15-20):1849-1852

Omar AH, Muda K, Toemen S, Sulaiman SF, Zaidi NS, Affam AC (2018) Study on the effect of a static magnetic field in enhancing initial state of biogranulation. J Water Supply Res Technol AQUA 67(5):484-489

Park C, Muller CD, Abu-Orf MM, Novak JT (2006) The effect of wastewater cations on activated sludge characteristics: effects of aluminum and iron in floc. Water Environ Res 78:31-40

Rahman MM, Kim W-S, Kumura H, Shimazaki K (2008) Autoaggregation and surface hydrophobicity of bifidobacteria. World J Microbiol Biotechnol 24(8):1593-1598. https://doi.org/10.1007/ s11274-007-9650-x

Rossetti S, Tomei MC, Nielsen PH, Tandoi V (2005) “Microthrix parvicella", a filamentous bacterium causing bulking and foaming in activated sludge systems: a review of current knowledge. FEMS Microbiol Rev 29:49-64

Sheng G-P, Yu H-Q, Li X-Y (2010) Extracellular polymeric substances (EPS) of microbial aggregates in biological wastewater treatment systems: a review. Biotechnol Adv 28:882-894

Tandoi V, Jenkins D, Wanner J (2006) Activated sludge separation problems. Theory, control measures, practical experience. IWA Publishing, London

Thompson G, Forster C (2003) Bulking in activated sludge plants treating paper mill wastewaters. Water Res 37:2636-2644

Tomska A, Wolny L (2008) Enhancement of biological wastewater treatment by magnetic field exposure. Desalination 222:368-373

Tsuneda S, Aikawa H, Hayashi H, Yuasa A, Hirata A (2003) Extracellular polymeric substances responsible for bacterial adhesion onto solid surface. FEMS Microbiol Lett 223:287-292

Van den Akker B, Beard H, Kaeding U, Giglio S, Short MD (2010) Exploring the relationship between viscous bulking and ammoniaoxidiser abundance in activated sludge: a comparison on conventional and IFAS systems. Water Res 44(9):2919-2929

Wang X-H, Diao M-H, Yang Y, Shi Y-J, Gao M-M, Wang S-G (2012) Enhanced aerobic nitrifying granulation by static magnetic field. Biores Technol 110:105-110

Wanner J, Jobbágy A (2014) Activated sludge solids separation. In: Jenkins D, Wanner J (eds) Activated sludge - 100 years and counting. IWA Publishing, London, pp 171-194

Yang SF, Li XY (2009) Influences of extracellular polymeric substances (EPS) on the characteristics of activated sludge under non-steady-state conditions. Process Biochem 44:91-96 
Yin X, Qiao S, Zhou J (2015) Using electric field to enhance the activity of anammox bacteria. Appl Microbiol Biotechnol 99(16):6921-6930

Zaidi NS, Muda K, Sillanpää M (2019a) Effects of extracellular polymeric substances towards physical properties of biomass under magnetic field exposure. Int J Environ Sci Technol 16(7):3801-3808

Zaidi NS, Muda K, Sohaili J, Hussein N, Loan LW, Sillanpää, M. (2019b) Potential of a static magnetic field to inhibit filamentous sludge bulking in activated sludge process. J Environ Eng 145(3):04019001-040190018

Zaidi NS, Muda K, Hussein N, Sillanpää M (2018) Potential inhibition of filamentous microorganisms in sludge bulking by static magnetic field. Int J Eng Technol (UAE) 7(3):15-17
Zaidi NS, Muda K, Sohaili J, Toemen S, Yusof NZ (2016) Optimization of operating parameters for aggregation under magnetic field by response surface methodology. ARPN J Eng Appl Sci 11(4):2419-2425

Zaidi NS, Muda K, Sohaili J, Sillanpää, M. (2014) Optimization of activated sludge physical properties by magnetic field via response surface modeling. Appl Mech Mater 567:98-103

Publisher's Note Springer Nature remains neutral with regard to jurisdictional claims in published maps and institutional affiliations. 